\title{
VOTING WITH THE SHILLING \\ The 'Money Talks Factor' in Kenya's Public Policy and \\ Electoral Democracy
}

\begin{abstract}
Wilson Muna and Michael Otieno
Wilson Muna is a lecturer of Public Policy at Kenyatta University, Nairobi

Michael Otieno is a lecturer at the Kenya Institute of Surveying and Mapping, Nairobi
\end{abstract}

\begin{abstract}
The influence of money in elections has become an important ingredient in determining electoral outcomes worldwide. The use of money in political activities has adversely affected the nature of public policy, governance, competition, the rule of law, transparency, equity and democracy. Although there are laws, policies and guidelines governing the use of money during elections, there is little political will to implement them. This paper examines how money, or the lack thereof, determines electoral outcomes in multi-party democracies with a focus on Kenya, employing both the hydraulic theory and the push-and-pull paradigm. The study found that in most cases, victory in elections follows those with money; in other cases, it is the potential for victory that attracts money from self-interested donors. The study calls on electoral bodies such as the Independent Electoral and Boundaries Commission to honour their mandate and demand compliance with set laws and regulations in a bid to entrench governance and create a level playing field for contestants.
\end{abstract}

Keywords: campaign financing; campaign spending; election money; electoral outcomes; Kenya; public policy

\section{INTRODUCTION}

The role of electoral campaign money in shaping public policy has become the new focus among policy analysts and political scientists. Elected officials usually avoid designing policies that respond to the needs of public since they are frequently under pressure to serve the interests of the donors to their election campaigns. Nobel prize winner Kenneth Arrow posited that economic inequality and the domination of powerful elites who influence the political system produce a 
form of democracy that represents the few rather than the majority, and turns a democratic government into a sham (Arrow 1978).

The advent of multi-party democracy in many countries has resulted in a significant increase in the cost of elections, with an increasing number of political parties and elective positions. In Kenya, for example, there were only three elective positions prior to the 2010 constitution: president, member of parliament, and councillor. Since then, the number of elective positions has doubled: the president; members of parliament (Senate, National Assembly, and Woman Representative), governor and county assembly seats. In Kenya, it is commonplace for the media, analysts and academics to set election agendas around issues of voter mobilisation, opinion polls, and election preparedness; yet, little, if any attention is paid to how money is mis/used to determine electoral results.

Ulen (2003) argues that in recent years staggering amounts are spent by major parties in every election cycle. The amount of money spent in elections, and its sources, have been of concern for many. In the 2002 elections alone (and this figure has significantly increased since then), the Republicans in the United States had at their disposal about $\$ 527.34$ million to spend, while the Democrats had \$343.7 million. According to Lowenstein and Hasen (2001), many individuals and groups that fund political election campaigns do so not for ideological reasons but as a way of soliciting political favours. For instance, funding for electoral candidates by the Widget Manufacturers Association of America is given with an expectation that legislation and other business regulations would be in their favour. Eme and Anyadike (2014, p. 22) hold that in Kenya, as in Nigeria, political parties are not usually founded on ideology. These contributions are made with strings attached in the form of concessions to acquire power and reap its rewards through the award of government contracts, commonly known as tenderprenuership. Yet, except in form of political rhetoric, little evidence exists which demonstrates the will to interrogate the source of such funding.

Even in the most developed democracies like the US, one of the major concerns for political parties and candidates running for elective office is the fear of influence of so-called 'dark money' in elections. This has threatened to destroy America's venerated democracy which has been exported the world over, and its potential threat is far from being assuaged. Lyles (2013, p. 285) states that the US governments' policy decisions are sympathetic towards American plutocracy, which includes its biggest presidential campaign donors. Research by Transparency International UK reported a popular perception that the richest segment of the population has the greatest power in society and is bound to grow more powerful than any government (Russell-Prywata 2018). Eme and Anyadike (2014, p. 22) also contend that elected officials in Kenya and Nigeria increasingly respond to their election campaign financiers in preference to the needs of their 
constituents. Funding by large corporates and wealthy individuals dictates political decision making. Such is the nature of the assault on democracy; yet, except in the form of political rhetoric, little evidence exists that demonstrates the will to interrogate the source of such funding.

The threat of money to democracy is obvious, but we cannot do without money or its influence in society and on the political system. According to a Gallup survey of Americans' views on campaign financing, 57\% of respondents felt that money contributed to candidates is akin to freedom of speech. However, a majority supported the enactment of rules and regulations governing campaign money. In addition, most supported a cap on contributions by individuals and corporations (Saad 2010).

Although academics and researchers have no verifiable evidence linking election spending and winning elections in the US (Stratmann 2005), it is worth exploring this hypothesis in the Kenyan context. In Kenya, it is commonplace for media, analysts and academics to set election agenda around issues of voter mobilisation, opinion polls, and election preparedness. However, little if any attention is paid to the role that money plays in influencing electoral outcomes. To some, elections are costing too much - to the distaste of either the public or the candidates themselves. For those unable to afford the initial fee to finance their election campaign, this entrenches the exclusion and disenfranchisement of those willing to compete for elective posts in the political process.

Fouirnaies (2018) analysed archival election data for the House of Commons in the UK and found that electoral costs shifted advantage to incumbents and those with more independent wealth. Most politicians form part of the moneyed elite and those who manage to get into office aspire to joining the club. Rossi (2010) studied the family histories of political elites in Buenos Aires and found that political power followed wealth. A study of political dynasties in the US Congress by Dal Bó, Dal Bó and Snyder (2009) found political power to be self-preserving. Relatives of long-serving members were more likely to join Congress in future, pointing to an unacknowledged rise of electoral nobility in contemporary times.

Arlen (2016) describes manipulation of the electoral system by the wealthy elite as a threat to constitutional democracy. Ancient Greek democracies like Athens, and early European democracies, had wealth qualifications as a requirement to run for office but these have since been abolished. Aristotle, notes Arlen, argues that wealth could be a measure but not a substitute for virtue. He further states that modern democracies may be under immediate threat of coups by the wealthy. The modern-day oligarch operates within the confines of the law, using their wealth to influence the distribution of resources, politics and public policy to their advantage. The unifying factor is the self-preservation of their class and wealth. Democracy in this way narrows down to rule by the rich few when it 
should be, by definition, the rule by the many, the poor, and the free. Jean Jacques Rousseau (1762) in The Social Contract surmises the view of what Arlen terms the 'oligarchic threat' to democracy by stating:

Nothing is more dangerous than the influence of private interests in public affairs, and the abuse of laws by the government is a less evil than the corruption of the legislator, which is the inevitable sequel to a particular standpoint.

Factors linked to the rising cost of electoral campaigns in Kenya include the increased number of voters; lucrative salaries and allowances associated with these electoral posts; expanding demand for hand-outs from elected officials by the electorate; the expanding public sector; increased levels of competition; changing platforms and instruments of effective campaigning; the open field of multi-party democracy; and the opportunities electoral positions present in controlling huge public funds.

The first section of this paper introduces background, context and significance, while the second section demonstrates the applicability of the theoretical frameworks proposed, the hydraulic theory and the push-and-pull paradigm. Section three explores evidence of campaign fundraising and spending, followed by an exploration of the regulations of campaign financing in section four. Section five reviews the money spent on the media in a bid to influence electoral outcomes. Section six reviews the relationship between money, electoral politics and public policy, while section seven concludes this study.

\section{THEORETICAL FRAMEWORK}

This work employs two critical theories in understanding the role of money in determining electoral outcomes, politics and public policy. These are the hydraulic theory, and the push-and-pull paradigm. Proponents of the hydraulic theory, Young and Jansen (2011, p. 178) posit that 'money, like water, will continue to seep into the political system. Reforms can change the direction that the money takes, but money will eventually seep back into the system as political actors identify and exploit loopholes in the law'. This theory underscores the challenge of policies to regulate campaign financing. Issacharoff and Karlan (1999, p. 1705) use two scientific analogies: firstly, Einstein's first law of political thermodynamics, to demonstrate that the desire for political power cannot be terminated, but at most channeled into different forms; and secondly, Newton's translation of the third law of political motion to mean that every attempt to limit political players results in an equal reaction by those with power to cling onto it. Political money 
will always find a way and is also part of a wider environment. They surmise that to understand political money, it has to be considered within the structure of the system. Yet, as Cross and Crysler (2011) opine, despite the efforts made to introduce campaign financing reforms and policies to contain money flows, money still finds its way back into the system as politicians exploit gaps within established laws.

Contrary to the hydraulic theory, Boatright (2011) proposed the push-andpull paradigm, which asserts that money is 'pushed' into the system by partisan or ideologically charged individuals or groups, and that money is also 'pulled' into the system by rent-seeking politicians. Corporations, labour unions and other interest groups often push their money into political campaigns, while at other times, politicians pull their money into their campaigns.

\section{Campaign Fundraising and Spending}

It is common belief that money is an important ingredient in winning elections. In order to limit the influence of private money on politics and public policy, Fisher (2011) called for the state to play a more active role in funding political parties and candidates, as a move to level the playing fields among competing parties. In his work, Money and Politics, Ulen (2003) argues that the growing relationship between private money and electoral competitions has attracted considerable scrutiny. In Kenya, Ohman and Lintari $(2015$, p. 25$)$ note that only about 10 per cent of the amount provided by law as state funding had been disbursed to political parties. Through the Centre for Multiparty Democracy Kenya (CMD-K) they found that only 3 of the 60 political parties registered as at 2013 received these funds. The total funds at 0.3 per cent of government revenue is, according to Ohman and Lintari, the highest in any African country taking into consideration purchasing power parity and size of population.

According to Terracino and Hamada (2014, pp. 5-8), public funding promotes the growth and performance of political parties and by extension the wider electorate's views and participation in a democracy. It minimises the uptake and influence of private money. Direct state funding of political parties could take three approaches: political parties may receive equal funding from the state; funding may be based on a party's past record; or a party may be reimbursed for some expenses based on its performance in the elections. Indirect financing takes the form of tax breaks and access to media.

Among the OECD countries, all but one provide public funds to political parties. During political campaigns, however, political parties lose financial discipline and their expenses exceed their incomes. Shapira (2019) is of the view that state funding should not be used for running costs and political campaign 
debts. In $43 \%$ of OECD countries, expenditure of public funds to political parties is predetermined (Terracino \& Hamada 2014, p. 9).

According to the Political Parties Act of 2011 in Kenya, this fund is expected to support parties in promoting their internal democracy and publicity, as follows:

- Promote the representation in both parliament and the county assemblies of women, persons with disabilities, youth, ethnic and other minorities, and marginalised communities;

- Promote active participation by individual citizens in political life;

- Cover the election expenses and policy broadcasts of the political party;

- Assist political party organisation of civic education in democracy and other electoral processes;

- Assist political party to influence the shaping of public opinion; and

- Cover the administrative and staff expenses of the political party.

Although such funding is available for political parties, smaller parties remain disadvantaged since allocation is computed proportionate to the votes garnered by each political party in the preceding general election. Since funding for a political party is pegged on its performance in a preceding general election, financial support for new parties formed before the next general election may not benefit from this form of financing. Also, independent candidates have not been considered under this Act, disadvantaging them from accessing public finance to advance their political agenda.

Kenya has also had to grapple with this question, culminating in the enactment of the Election Campaign Financing Act of 2013. This Act was drafted to provide for the regulation, management, expenditure, and accountability of election campaign monies. The Act views campaign financing as 'resources spent by a candidate or a political party during an election period for purposes of campaign'. According to the Act, such financing is to be solicited from three main sources:

1. Contributions received from any person, political party or any other lawful source;

2. Contributions from a lawful source, not being directly from a foreign government; and

3. Contributions from a Harambee (self-help campaign fundraising). 
The Election Campaign Financing Act also envisages a set limit on contributions meant for the purposes of campaign financing. The IEBC is expected therefore to manage this process by prescribing the limits at least 12 months before the date of the general election, relating to: total contributions; contributions from a single source; paid-up media coverage; and any loan forming part of a contribution which an aspirant or a political party may receive during the expenditure period. Although the Commission has capped contributions from external sources at 20 per cent of the total aspirant's campaign fund, no clear measures have been proposed to disclose such sources for public scrutiny. While the Commission is required by the Act to make this information available on request, such a limited window is clouded by confidentiality requirements. As Ohman (2012, p. 39) found, most countries require financial reporting which is not conducted, despite it being the best method to ensure transparency. The reports include the identity of donors but very few countries have donation limits or sanctions for flouting the regulations.

On 8 August 2016, exactly one year before the 2017 general elections and in line with the law, the IEBC published a notice in the Kenya Gazette on the contribution limits that a political party may receive during the campaign expenditure period. Any political party was therefore limited to receiving a total contribution of KSh. 15030950000.0 with the total contribution from a single source capped at KSh. 3000190000.0 (20\% of the total contribution, as per Section Election Campaign Financing Act, 2013). The Gazette notice demarcates the expenditure period to six months before the campaign period (8 February 2017 to 8 August 2017).

The Commission envisages that specified campaign finance funds be spent in two phases: (a) to fund the operations of the party primaries; and (b) to fund the expenses between the party primaries and the date of the general election. The Commission further authorises specific items or activities for which campaign spending may be incurred, as demonstrated in Table 1 below.

The Act has not only put a limit on the amount candidates may receive, but also how much a candidate or a political party may spend, depending on the following factors: geographical features, including urban centres; the type of election; the population in an electoral area; the number of party members in an electoral area; and the communication infrastructure in an electoral area. Despite the fact that the Act demands that candidates or political parties that spend beyond certain limits file a report with the Commission, there is scant if any evidence of this in the public domain. The Gazette Notice No. 6307 on limits to contributions and spending ahead of the general elections on 8 August stipulates that 'a person convicted of an offence under the Election Campaign Financing Act, 2013 for which no penalty is provided shall be liable to a fine not exceeding two million shillings or a term of imprisonment not exceeding five years or to both'. 


\section{Table 1: Schedule on nature of authorised items and activities and respective costs}

\begin{tabular}{|c|c|c|c|}
\hline & Party Primaries & $\begin{array}{l}\text { Expenses after } \\
\text { Party Primaries }\end{array}$ & \\
\hline Item & Total Limit (KSh) & Total Limit (KSh) & Grand Total \\
\hline Venues & 450000000 & 9400000 & \\
\hline $\begin{array}{l}\text { Publicity materials (infor- } \\
\text { mation, education and } \\
\text { communication) }\end{array}$ & 700000000 & 700000000 & \\
\hline Advertising and Media & 150000000 & 150000000 & \\
\hline $\begin{array}{l}\text { Nomination (party prima- } \\
\text { ries) }\end{array}$ & 550000000 & - & \\
\hline Party Dispute Resolution & 100000000 & 3000000 & \\
\hline Campaign personnel & 30000000 & 435000000 & \\
\hline Campaign Agents & - & 870000000 & \\
\hline Election Agents & - & 880000000 & \\
\hline Transportation & 13050000 & 130500000 & \\
\hline Administrative costs & 45000000 & 100000000 & \\
\hline Communication & 90000000 & 200000000 & \\
\hline $\begin{array}{l}\text { Marketing (launches, } \\
\text { research, advocacy, policy / } \\
\text { manifesto crafting, brand- } \\
\text { ing etc.) }\end{array}$ & 1595000000 & 5800000000 & \\
\hline Mobilization & 90000000 & 200000000 & \\
\hline Security & 145000000 & 725000000 & \\
\hline Accommodation & 90000000 & 200000000 & \\
\hline Other justifiable expenses & 80000000 & 500000000 & \\
\hline Total & 4128050000 & 10902902000 & 15030950000 \\
\hline
\end{tabular}

Source: Government of Kenya, 2013

The Commission, through the Kenya Gazette (First Schedule) set a limit for the presidential campaign at a massive KSh. 5247588207.74 to cover the 47 counties. With regard to county elections, varying limits have been established according to the size of the population and the geographical area of respective county jurisdictions. According to the Second Schedule, the contributions for respective county elective positions (Governor, Senator and County Woman Member of the 
National Assembly) range between KSh. 432877539.96 for Nairobi at the high end and KSh.13 111370.92 for Lamu County, at the low end.

The Third Schedule of the Gazette sets a limit on contributions for candidates vying for each of the 290 constituencies in Kenya. Limits for parliamentary positions are custom-made for each constituency, taking into consideration the size of their population and geographical expansion. The limits set by the commission range between KSh.33 402771.08 for Mandera South to KSh. 141 037.00 for Nyando Constituency. Lastly, the Fourth Schedule of the Gazette Notice by the Commission also set a limit on contributions for candidates in elections in County Assembly Wards. In respect of population and geographical area, the limit for the position of the County Assembly Ward ranges from between KSh. 10321669.69 for Elwak South in Madera County to KSh. 68884.07 for Fafi County Representative Ward in Garissa County.

Election laws and guidelines notwithstanding, the Auditor-General in his report (cited in Gaitho 2018) revealed that most political parties have weak internal controls while some have poor bookkeeping records without requisite details being prepared or available for verification. It is apparent that there was little if any political will to abide to election finance regulations.

In countries like the United States, presidential campaigns since the $19^{\text {th }}$ century have relied largely on private contributions. By 2013, the monetary spending on US presidential campaigns had risen sharply. According to Levy, Hartwick, Munoz, and Gudgel (2014), combined expenditure on presidential and congressional elections has more than tripled in just 15 years. At the same time, 'the U.S. corruption perception index recently increased, ranking worse than any other industrialized nations' (Kiely 2012).

In Kenya, the cost of the general elections has risen steeply, with an estimation of close to 130 million dollars (13 billion Kenya Shillings) spent on presidential campaigns ahead of the 2013 elections. Maina (2013) concurs with Mwaura and Mungai that much of this goes on travel, operations, events, and media adverts as well as merchandising (see Figure 1).

Drawing on aviation industry data on political parties, Maina (2013) notes that the 2013 presidential campaign expenditure listed the Jubilee coalition having six helicopters and four fixed wing planes; Coalition for Reforms and Democracy (CORD) had four helicopters and two fixed wing planes; Eagle coalition five helicopters and one fixed wing; and Amani coalition had one helicopter at their disposal. The hiring rate for helicopters is $\$ 1500-\$ 2000$ per hour, and fixed wings about $\$ 1700$ per hour.

As Mwangi (2018) analysed, presidential campaign advertisement expenditure from 1 January 2017 to 4 August 2017 revealed the following: the Jubilee coalition spent KSh 312141 620.00, National Super Alliance (NASA) coalition 
KSh 155153 840.00, Maendeleo Chap Chap party KSh 1812 300.00, Party of National Unity (PNU) KSh 1725 600.00, Orange Democratic Movement (ODM) party KSh 1350 410.00, Liberal Democratic Party (LDP) KSh 73000.00 and the National Agenda Party KSh 50 000.00. Maendeleo Chap Chap and PNU supported Jubilee coalition's presidential candidate Uhuru Kenyatta, whereas ODM was a coalition partner in the NASA coalition whose presidential candidate was Raila Odinga.

Comparing these figures to the Election Act limits set on advertisement expenditures reveals that the Jubilee coalition overspent. However, due to the confidentiality clause of the Act, the reporting on expenditure cannot be exhaustively interrogated. Kenya's presidential election results of $2013 \mathrm{had}$ Jubilee's candidate garner 6173433 votes, CORD's 5340 546, Amani's 483 981, and Eagle's 72786 (IEBC, 2013). In the nullified 2017 presidential results, Jubilee had 8203290 to NASA's 6762 224. Interrogating these figures vis-à-vis presidential election results brings into perspective the findings by Muna, Shulika and Mutula (2014) and Abdulwaheed, Adebeyi, and Bakare (2018) on the impact of money in electioneering. Issacharoff and Karlan (1999, p. 1709) contend that spending on mass media is the most effective form of influence, as the electorate is vulnerable to misinformation and disinformation, deliberate or otherwise.

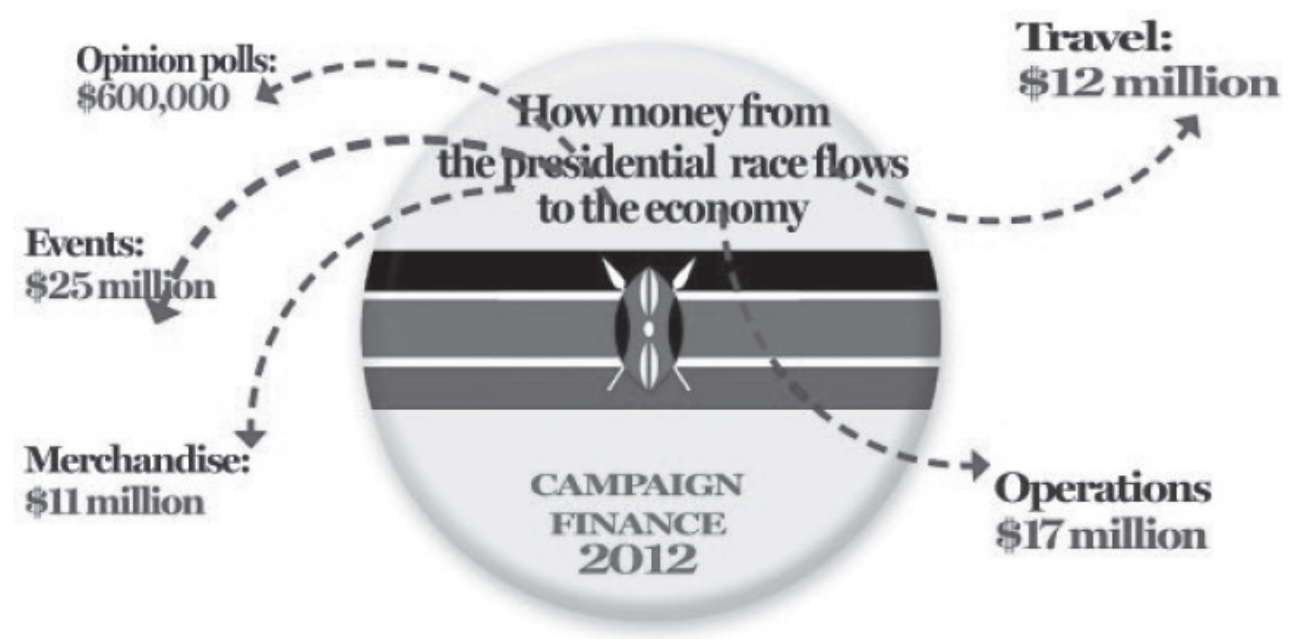

Figure 1: Campaign Finance and Expenditure, 2012

(Source: Mwaura \& Mungai, 2012) 
In the 2016 US Presidential election, Hillary Clinton outspent Donald Trump's campaign by $\$ 768$ million to $\$ 398$ million. This in itself could not overcome Trump's dominance of media headlines. In the final analysis, Donald Trump's eccentricity earned him $\$ 5.9$ billion worth of free media, compared to Hillary Clinton's $\$ 2.8$ billion. There was a decline in campaign spending compared to the 2012 election but the value of the free media cannot be ignored. It was also found that most of the campaign financing was by a few top donors with a drop of 3.4\% in the number of smaller contributions from individuals (Allison, Rojanasakul, Harris, \& Sam 2016; Ingraham 2017; Sultan 2017). Dawood (2014, p. 15) cites Ensley (2009), La Raja and Wiltse (2011), and Johnson (2010) in asserting that extreme candidates raise more money from individual donors who are more aligned to their own social and political beliefs. This illustrates how the electoral process becomes increasingly partisan and elitist.

In many developing countries, policy measures have been introduced as an effort to cap campaign spending. Such attempts have been tried in other countries, such as the US and Canada (Young \& Jansen 2011). Ohman (2012, p. 36) used data from the IDEA database and found that very few countries have instituted campaign spending limits on parties, with almost half setting limits to individual candidates' spending. The American Federal Election Campaign Act (FECA) of 1971 had capped election spending, setting a limit on how much could be spent by an aspirant, a private supporter, or any organisation working independently to support the aspirant (Brubaker 1998).

In Canada, attempts have been made to enact legislation to regulate the influence of money in politics. Speaking to the House of Commons, then Prime Minister Jean Chretien maintained that the bill would 'address the perception that money talks, that big companies and big unions have too much influence on politics ... and reduce cynicism about politics and politicians, a bill that is tough but fair' (Young \& Jansen 2011). Findings by Fouirnaies (2018) credit the levelling of the electoral competition playing field to campaign finance regulations.

The outcome of campaign spending remains an important research question, and responses to this question raise increased interest now that incumbency re-election has become the new order in many countries. Stratmann (2005) in an educated guess links incumbents with their ability to outspend their opponents, since on average more than $75 \%$ of their supporters fund their election campaigns. Since the advent of multi-party election in 1992 in Kenya, no incumbent president has yet lost a re-election.

\section{Media, Money and Political Advertising}

The media has a powerful and effective role in shaping public opinion. According to Nyanjom (2012) the political elite have invested in media houses not only 
for commercial reasons but more importantly, and pragmatically, for political influence. Bornstein (1989) asserted that repeated exposure to a particular candidate's message makes the electorate more inclined to accept the message and accompanying symbols. During political campaigns, spending on media and advertisements takes up the largest percentage share of political campaign expenses (Mwangi 2018).

It can be inferred therefore that those without money and with less access to media are technically knocked out from participating in electoral competition. Potter (2012) surmises that exposure to the media influences the individual at many levels, in terms of logic, emotion, behaviour and even physiology. The most important role of the media in a democracy is that of informing the public and providing a platform to debate ideas. Media bias can be used to derail the democratic process as bias in reporting may influence the individual voter to support a particular position (Entman 2007).

Coxall, Robins, and Leach (2003) highlight media communication as an important aspect of politics, as radio and TV advertising and campaigning add to the value and cost of political campaigns. Increased professionalism in marketing strategies has dug deep into the coffers of candidates and political parties. Due to security concerns, particularly in urban environments, it is less likely that candidates and their supporters will provide access to strangers in door-to-door campaigning, which is increasingly seen as an archaic strategy. Therefore, in order to sell their ideas, political parties and candidates are forced to invest more in high-tech ads in a bid to seek public attention and approval.

The impact of mass media on politics has been the topic of much analysis. Aside from informing the electorate and facilitating democracy, it has been described as anti-democratic as it can be manipulated, particularly by those with money, and real issues of public concern can be trivialised. Politicians invest in media houses and media owners play 'kingmaker'. Beltrán and Hite (2019) describe how in Guatemala, the media is owned by a few individuals who wield great political and economic power. Some powerful media owners channeled over $\$ 23$ million to support Molina's re-election campaign in exchange for up to $69 \%$ of government television advertising between 2012 and 2015 .

The amount of money available and spent in the media on political advertising is on the rise, owing to the general belief among political candidates and voters that money influences election outcomes. Political advertising in the media has been accelerated by campaign committees, political parties and individual candidates for different reasons. These include political tools to keep voters motivated, to provide more information to undecided voters, and to discredit and dissuade potential voters from their opponents, all with the endgame of winning elections (Simoes 2013). 
In Brazil, for example, results from a study by Da Silveira and De Mello (2011) presented empirical evidence regarding Brazilian elections indicating that the effects of media campaign advertising were felt more strongly in underprivileged and less-educated communities where there was less knowledge about parties and candidates on the ballot. While interrogating the effect of the image-based assessment of US Senate and gubernatorial candidates and election performance, Lenz and Lawson (2011) found that attractive-looking politicians benefit significantly from TV exposure, particularly among voters in localities with less education. The fact that money spent on media political campaign advertising is on the rise, as in Kenya and the U.S., does not translate to proof that this kind of investment has any significant impact. Nonetheless, academics and researchers are yet to decide on whether media political campaign advertising has any effect on election results.

\section{Corruption and Election Funding}

Corruption has been cited as a key element in undermining electoral democracy. According to Eme and Anyadike (2014, p. 23) demand for huge amounts of cash to be used in election campaigns is a pointer towards potential grand corruption. In their comparative study of political financing in Kenya and Nigeria (ibid.), results indicated that large companies and single donors to parties and individual candidates dominate political decisions, making it harder for small companies and groups to access social, political and economic networks and resources.

Eme and Anyadike (2014, p. 23) further noted that nearly all key financial scandals in recent years have been linked to political campaign and financing. In Kenya, for example, proceeds of the Goldenberg scandal (in which billions were lost in a well-choreographed scheme that implicated top officials in Moi's government) financed the Kenya African National Union's (KANU) elections of the 1990s. Another grand scandal - the Anglo-Leasing affair - was designed and executed to finance the 2007 elections for the National Rainbow Coalition (Mwangi 2008).

In describing the prevalence of vote-buying in developing democracies, Fredric and Andreas (2005) averred that political candidates buy and the electorate sell their votes as products in the market. These entrepreneurial activities are regarded as a contractual relationship whereby individual voters are bound to cast their votes for a political party or candidates on election day. Monetary politics is cited as a dominant factor in vote-buying, bribery and intimidation and has been central to the violation of electoral justice in Kenya.

According to Abdulwaheed et al. (2018), vote-buying and the prevalence of money in the management of electoral politics in African democracies do not happen in a vacuum, and are informed by their context. Key among these include: 
- the inability or unwillingness of political parties to design clear manifestos for voters to base their choice on;

- pessimism expressed by voters that political candidates are corrupt and that nothing can be done to change the status quo;

- voters focus on individual popularity (cult of personality) instead of public issues and concerns;

- voters' obsession with the extravagant lifestyle of politicians; and

- the hankering by politicians to win elections at all cost and to defend their positions by all means (Davies 2006).

Another aspect linked with political corruption is the use of state resources during political campaigns, which often blurs the distinction between the governing party and state resources. Although there is distinction in law between the governing party and the state, the Commonwealth Observation Team (cited in Falguera, Jones \& Ohman 2014, p. 18) highlighted that in Gambia, 'blurring of state and party lines was evident throughout the President's campaign'. In the 2007 Kenyan general elections, it is estimated that about 500 million Kenya shillings worth of state resources went to fund President Kibaki's re-election campaign (ibid.).

Parties in African countries like Kenya, Ghana, and Sierra Leone sell their nominations to candidates with the ability to pay to enhance their chances of nomination. Instead of parties creating a level playing field where candidates interested in being nominated by particular parties compete through nominations by party membership, candidates with the highest bids receive party nomination. As Falguera et al. (2014) posit, more money flows during party nominations than at any other time in the campaign period. In localities with strong party loyalties, being nominated by the popular party literally guarantees electoral victory. Thus, candidates are selected for their ability to raise funds, which disadvantages those with less access to funding.

\section{Money, Electoral Politics and Public Policy}

Those with access to money tend to shape the nature and character of politics and public policy in any given country. The relationship between the use of money during electoral campaigns and the nature and quality of public policy delivery has elicited an important interest. In their study, results by De Figueiredo and Edwards (2007) indicated that there was a significant link between the use of money in political campaigns and telecommunications regulatory policy outcomes. The strength of their findings was founded on conventional arguments: that campaign contributions had a bearing on the outcomes of public policy in critical sectors. 
In tandem with the foregoing, De Figueiredo and Edwards (2007) posit that private contributions to electoral campaigns have shifted the common discourse from 'regulation for the public interest' to 'regulation for political interests'. Thus, private donors provide monetary support to parties and candidates with the expectation that winners will eventually use their political power to change or maintain key policies in their favour, and enact policies that might keep their competitors at bay. Baron (cited in De Figueiredo \& Edwards 2007) comments that the only way private actors can influence public policies in their favour is through contributions to election campaigns. In the end, contributors to the electoral campaign must be in a relationship founded on mutual trust and loyalty with elected officials in order to receive specified favours as rewards for their contributions (Snyder 1992).

In such an environment, those with ideas but no money are forced to make extra efforts and be extremely persuasive in order to win elective positions. According to Bakari (2002, p. 271), politics in Kenya has been seen as an exclusive space for the rich. He asserts that:

He who had money controlled politics, and Moi used money, or access to money in the form of government contracts, high governmental positions that were virtually sinecure, and in the last decade, access to land. The months leading to the first multi-party elections in 1992 was the high point in the abuse of public land. Government land became KANU's new cash cow. It was a shortcut to instant wealth and a source of campaign cash.

The question of whether money determines election victory or has the potential to do so has merits, though it is still contestable. Inevitably, the candidate who spends more is most likely to win (Dawood 2014, p. 15). According to Bonica (2017) big donors in America have access to polling data and disburse their money to candidates based on ratings and popularity. Either way, money finds its way into the electoral and political process either before, during or after elections. Dawood (2014, p. 16) surmises that though money may impact the policy process, empirical data is difficult to obtain.

Other factors aside, it is evident that access to and use of money in developing democracies in Africa is the weakest link toward the realisation of ethical electoral governance and democracy. Muna et al. (2014) studied the impact money had on presidential election outcomes in Kenya (with a focus on the 1992 to 2013 presidential elections) and concluded that money, or lack thereof, was a major determining factor toward winning or losing an election.

As Abdulwaheed et al. (2018) argued, electoral outcomes, especially in African democracies, have frequently been influenced by the wealth of the 
candidate(s) or their parties. Equally, he argued that this is not a new phenomenon in Africa, considering that rulers and contenders for public office have throughout history leveraged power through the wealth they own or control. The economic strength of a candidate's political base gives them an edge over rivals, competitors, and detractors. The modern political landscape is replete with political systems in which rulers and governing bodies across continents - monarchs, military dictators, elected heads of state, and legislators - rely on their economic and financial influence, whether ill-gotten or legitimately accumulated, to gain access to and/or maintain political power (Muna et al. 2014). In the end, this phenomenon provides the grounds for more causal research, but this study makes broad conclusions that money moving within the electoral system, whether pushed or pulled, eventually shapes emerging public policy decisions.

\section{CONCLUSION}

Developing democracies in Africa are grappling to regulate electoral campaign financing with varying degrees of success. Such measures have not always been effective as they are often curtailed by confidentiality clauses. Although political parties and politicians are expected to report money collected and used in their campaigns, no clear mechanisms have been put in place for media and public audit, and this renders it difficult to guarantee transparency and accountability. In most cases, measures to curb electoral financial fraud are not sufficiently punitive to act as a deterrent and encourage compliance. This study concludes that money has always found its way through the political system. The article also indicates how money has a corrupting effect on the electoral process. Candidates with the ability to mobilise more campaign finances are seen as buying their way to win elections, while those championing a transformative agenda are ignored. In order to transform electoral democracy and justice, this study calls for a comprehensive policy intervention in order to regulate the role of money in determining electoral outcomes. Despite influential political actors exploiting legal gaps, successful electoral reforms must focus on reducing the cost of campaign financing. In every election cycle, an independent body should continue to monitor and suggest ways to limit the use of money in wooing voters. And since money has often been cited as the root cause of bad governance, limiting the amount of money flowing, or being pushed into the system is the obvious remedy. 


\section{----- REFERENCES}

Abdulwaheed, A, Adebiyi, OM. \& Bakare, AR 2018, 'Ethnicity and election outcomes in Nigeria: interrogating the 2015 presidential election', Journal of African Elections, vol. 17, no. 1, pp.117-139.

Allison B, Rojanasakul M, Harris, B \& Sam, C 2016, 'Tracking the Presidential Money Race', Bloomberg. Available at: https://www.bloomberg.com/ politics / graphics / 2016-presidential-campaign-fundraising/

Arlen, G2016, 'Aristotleand the problem of oligarchicharm:insightsfordemocracy', European Journal of Political Theory, vol. 18, Issue 3, pp. 393-414 . Available at: https: / /journals.sagepub.com/doi/pdf/10.1177/1474885116663837

Arrow, KJ 1978. 'The future and the present in economiclife', Economic Inquiry, 16(2), pp.157-169.

Bakari, M 2002, 'Kenya Election 2002: The End of Machiavellian Politics?', Alternatives, Turkish Journal of International Relations, vol. 1, no. 4.

Beltrán A \& Hite A 2019, 'Corruption in the Guatemalan Political System and the 2019 Elections', 12 June, Available at https://www.wola.org/analysis/ corruption-in-the-guatemalan-political-system-and-the-2019-elections /

Boatright, RG 2011, Interest groups and campaign finance reform in the United States and Canada, University of Michigan Press, Ann Arbor, MI.

Bonica, A 2017, 'Professional Networks, Early Fundraising, And Electoral Success', Election Law Journal: Rules, Politics, and Policy, vol. 16, no. 1, https:// doi. $\operatorname{org} 10.1089 /$ elj.2016.0413

Bornstein, RF 1989, 'Exposure and affect: overview and meta-analysis of research, 1968-198', Psychological bulletin, vol. 106, no. 2, p.265.

Brubaker, SC 1998, 'The limits of campaign spending limits', The Public Interest, no. 133, pp. 33ff.

Cross, W \& Crysler, J 2011, 'Financing party leadership campaigns', in Money, Politics and Democracy: Canada's Party Finance Reforms, University of British Columbia Press, Columbia.

Dal Bó, E, Dal Bó, P \& Snyder, J 2009, 'Political dynasties', The Review of Economic Studies, vol. 76, no. 1, pp. 115-142. https:/ / www.jstor.org/stable/ 20185086 Da Silveira, B \& De Mello, J 2011, ‘Campaign Advertising and Election Outcomes: Quasi-Natural Experiment Evidence from Gubernatorial Elections in Brazil', Review of Economic Studies, vol. 78, no. 2, pp. 590-612.

Dawood, Y 2014, 'Campaign Finance and American Democracy', Annual Review of Political Science, vol. 18, pp. 329-348.

De Figueiredo Jr, RJ \& Edwards, G 2007, 'Does private money buy public policy? Campaign contributions and regulatory outcomes in telecommunications', Journal of Economics \& Management Strategy, vol, 16, no. 3, pp.547-576. 
Eme, OI \& Anyadike, N 2014, 'Political Financing in Africa: A Comparative Study of Kenya and Nigeria: Proposal for Reform', Mediterranean Journal of Social Sciences, vol. 5, no. 27, pp. 22-34.

Ensley, M 2009, 'Individual campaign contributions and candidate ideology', Public Choice, vol. 138, pp. 221-238.

Entman, RM 2007, 'Framing bias: Media in the distribution of power', Journal of communication, vol. 57, no. 1, pp.163-173.

Falguera, E, Jones, S \& Ohman, M. (eds) 2014, Funding of political parties and election campaigns: A handbook on political finance, IDEA, Stockholm.

Fisher, J 2011, 'State funding of political parties: truths, myths and legends', in Young, L \& Hansen, HJ (eds) Money, Politics, and Democracy, UBC Press, Vancouver.

Fouirnaies, A 2018, How Do Campaign Spending Limits Affect Electoral Competition? Evidence from Great Britain 1885-2010, University of Chicago, Chicago.

Gaitho, PR 2018, 'An Assessment of Financial Reporting and Auditing Practices in County Governments of Kenya', Journal of Public Administration and Governance, vol. 8, no. 4.

Hasen, RL 2001, 'Bush v. Gore and the future of equal protection law in elections', Florida State University Law Review, vol. 29, issue 2, pp. 377-406.

Independent Electoral and Boundaries Commission 2019, 4 ${ }^{\text {th }}$ March 2013 General Election; Election Data. Available at: https://www.iebc.or.ke/ election/ ?Election_Results (Viewed 18 June 2019)

Ingraham, C2017, 'Somebody JustPuta Price Tag on the2016Election. It's ADoozy', The Washington Post,14 April . Available on: https:/ / www.washingtonpost. $\mathrm{com} /$ news/wonk/ wp/2017/04/14 / somebody-just-put-a-price-tag-onthe-2016-election-its-a-doozy $/$ ?noredirect $=$ on\&utm_term $=.399 f 4 c 7 d 20 f 8$

Issacharoff, S \& Karlan, PS 1999, 'The Hydraulics of Campaign Finance Reform', Texas Law Review 1998-1999, vol 77, pp. 1705-1738.

Kenya Gazette 2016, 'Limits on contributions for political parties for the general election scheduled to be held on $8^{\text {th }}$ August, 2017', The Independent Electoral and Boundaries Commission Act (2016), Government Printers, Nairobi.

Kiely, K 2012, 'Money in Politics Drives up US Corruption Perception Index', Sunlight Foundation.

La Raja R, Wiltse D 2011, 'Don't blame donors for ideological polarization of political parties: ideological change and stability among political contributors, 19722008', American Politics Research, vol. 40, pp. 501-30.

Lenz, GS \& Lawson, C 2011, 'Looking the part: Television leads less informed citizens to vote based on candidates' appearance', American Journal of Political Science, vol. 55, no. 3, pp. 574-589.

Levy, B, et. al., 2014, 'What's Money Got to Do with It? Fostering Productive 
Discussions about Campaign Finance', The Social Studies, vol. 105, no. 5, pp. 213-105.

Lyles, LD 2013, 'The Role of Wealth and Neoliberalism in Barrack Obama's Selection, Election, and Presidency', The Journal of Pan African Studies, vol. 6, no. 6, pp. 277-302.

Maina, W 2013, 'The Money Factor in Race for Kenya's Top Job', Business Daily, Friday March 1, Available at: https://www.businessdailyafrica.com/ magazines / The-money-factor-in-race-for-Kenya-top-job / 12489281707256-useumn/index.html (accessed on 201906 19).

Muna, WK, Shulika, LS, \& Mutula, S 2014, 'Monetary clout and electoral politics in Kenya-the 1992 to 2013 presidential elections in focus', Journal of African Elections, vol. 13, no. 2, pp. 196-215.

Mwangi, A 2018, 'You are to blame for our ' greed', MPs tell Kenyans', People Daily, 8 July.

Mwangi, W 2018, 'How Jubilee and NASA Spent Millions on Election Campaigns', The Star, 9 January. Available on https:/ / www.the-star.co.ke/news/201801-09-how-jubilee-and-nasa-spent-millions-on-election-campaigns /

Mwaura, C \& Mungai, C 2012, 'Campaign Finance: Price Tag of Kenya 2012 Presidential Race Likely To Hit $\$ 130$ Million', The East African, 5 February. Available at: http:/ / www.theeastafrican.co.ke/news/Campaign-finance-Price-tag-of-Kenya-2012-presidential-race/2558-1320582-ycx0ycz/index. html. [Accessed on 31 July 2017].

Nyanjom, O 2012, Factually true, legally untrue: Political media ownership in Kenya, Internews, Nairobi.

Ohman, M 2012, Political Finance Regulations around the World; an Overview of the International IDEA Database, IDEA: Stockholm. Available at: https: / / www. idea.int/ sites / default/ files / publications / political-finance-regulationsaround-the-world.pdf (accessed 2 July 2019).

Ohman, M \& Lintari, C 2015, Political Party Financing and Equal Participation of Women in Kenyan Electoral Politics: A Situation Overview, IDEA, Stockholm. Available at: https://nimd.org/wp-content/uploads/2017/10/Politicalparty-financing-in-Kenya-International-IDEA-and-NIMD.pdf

Potter, WJ 2012, Media effects, Sage Publications, Thousand Oaks, Calif.

Rossi, MA 2010, 'The Origins of Political Power: The Role of Wealth', Universidad De San Andres: Argentina . Available at: https://www.bcu.gub.uy/ Comunicaciones / Jornadas\%20de\% 20Economa / iees03j3431010.pdf [accessed 15 July 2019).

Russell-Prywata, L 2018, 'Corruption, Wealth \& Political Power', Transparency International UK. Available at:https://www.transparency.org.uk/ corruption-wealth-political-power/ 
Saad, L 2010, 'Public Agrees with Court: Campaign Money Is "Free Speech"; But Have Mixed Views on Other Issues at Heart of New Supreme Court Ruling', Gallup, Princeton, NJ. Available at: https://news.gallup.com/ poll/125333/ public-agrees-court-campaign-money-free-speech.aspx

Schaffer, FC \& Schedler, A 2005, 'What is Vote Buying? The Limit of the Market Model', Paper presented at the conference on Poverty, Democracy and Clientism: The Political Economy of Vote Buying, Stanford University Bellagion Center, Rockefeller Foundation, 28 November-2 December 2005.

Shapira, A 2019, 'The Absurdity of Campaign Financing in Israel', The Times of Israel, 5 July. Available at: https://blogs.timesofisrael.com/the-absurdityof-campaign-financing-in-israel/

Simoes, JP 2013, 'Can elections be bought? Analysing the relationship between money and success in political campaigns', MSc thesis, School of Business and Economics, Maastricht University.

Snyder, J 1992, 'Long-Term Investing in Politicians: Or, Give Early, Give Often,' Journal of Law and Economics, vol. 35, pp. 15-43.

Stratmann, T 2005, 'Some talk: Money in politics. A (partial) review of the literature', In Policy challenges and political responses, pp. 135-156, Springer, Boston, MA.

Sultan, NM 2017, 'Election 2016: Trumps Free Media Helped Keep Cost Down, But Fewer Donors Provided More of the Cash', OpenSecrets.org, 13 April. Available at: https: / / www.opensecrets.org/news/2017/04/election-2016trump-fewer-donors-provided-more-of-the-cash /

Terracino JB \& Hamada Y 2014, Financing Democracy, Supporting Better Public Policies and Preventing Policy Capture, OECD: [Paris].

Ulen, TS 2003, 'Money and Politics', University of Illinois Law Review, vol. 4, pp. 1037-1072.

Young, L \& Jansen, HJ 2011, Money, politics, and democracy: Canada's Party Finance Reforms, UBC Press, Vancouver. 